\title{
Simultaneous removal of heavy metals from drinking water by banana, orange and potato peel beads: a study of biosorption kinetics
}

\author{
Risha Jasmine Nathan ${ }^{1,2} \cdot$ Candace E. Martin ${ }^{2} \cdot$ Dave Barr $^{3} \cdot$ Rhonda J. Rosengren $^{1}$ (D)
}

Received: 7 April 2020 / Accepted: 15 June 2021 / Published online: 22 June 2021

(c) The Author(s) 2021

\begin{abstract}
Banana, orange and potato peels (BP, OP and PP, respectively) were immobilised to produce biosorbent beads that were employed for the biosorption of heavy metals from a cocktail solution containing $\mathrm{As}(\mathrm{V}), \mathrm{Cd}(\mathrm{II}), \mathrm{Cr}(\mathrm{VI}), \mathrm{Cu}(\mathrm{II}), \mathrm{Hg}(\mathrm{II})$ and $\mathrm{Ni}(\mathrm{II})$ ions. Drinking water conditions were maintained with neutral initial $\mathrm{pH}$ and low concentration of the ions. Batch experiments were performed for evaluating the effect of $\mathrm{pH}$ in the drinking water range (6.5-8.5). Results showed a significant increase in the biosorption capacity of the beads with respective to the uptake of $\mathrm{As}$ and $\mathrm{Pb}$, whereas it decreased significantly for $\mathrm{Cd}, \mathrm{Cu}, \mathrm{Hg}$ and $\mathrm{Ni}$ ions at basic $\mathrm{pH}$ values. Approximate equilibrium biosorption of $\mathrm{Cd}, \mathrm{Cu}, \mathrm{Hg}$ and $\mathrm{Ni}$ was $89-92 \%$, $79-87 \%, 84 \%$ and $71-80 \%$ by BP, OP and PP beads. The physisorption-based PFO model was the most suitable for the ions with biosorption capacities closer to the experimental values. BP and OP beads had better biosorption efficiencies relative to PP bead due to the higher surface heterogeneity observed by scanning electron microscopy coupled with energy-dispersive spectroscopy. An increase in the biosorbent concentration from one to ten BP beads significantly increased the biosorption percentage of the ions. The biosorption capacities of $\mathrm{Cd}, \mathrm{Hg}$ and $\mathrm{Ni}$ uptake by one BP bead from a $1 \mathrm{mgL}^{-1}$ cocktail solution were $3.4 \pm 0.0,5.3 \pm 0.1$ and $3.0 \pm 0.0 \mathrm{mgg}^{-1}$, respectively. Thus, BP beads were the most effective than for the simultaneous removal of heavy metals from drinking water.
\end{abstract}

Keywords Banana peel $\cdot$ Orange peel $\cdot$ Potato peel $\cdot$ Sodium alginate bead $\cdot$ Biosorption $\cdot$ Heavy metals

\begin{tabular}{|c|c|c|c|}
\hline \multicolumn{2}{|c|}{ Abbreviations } & $c_{\text {ad }}$ & Concentration adsorbed \\
\hline \multirow{5}{*}{$\begin{array}{l}\text { As } \\
\text { AP } \\
\text { BP }\end{array}$} & Arsenic & $\mathrm{Cd}$ & Cadmium \\
\hline & Apple peel & $\mathrm{CP}$ & Cucumber peel \\
\hline & Banana peel & $c_{\mathrm{o}}$ & Initial concentration \\
\hline & & $\mathrm{Cr}$ & Chromium \\
\hline & & $c_{\mathrm{t}}$ & Concentration at time ' $\mathrm{t}$ ' \\
\hline \multirow{8}{*}{$凶$} & Rhonda J. Rosengren & $\mathrm{Cu}$ & Copper \\
\hline & rhonda.rosengren@otago.ac.nz & EDS & Energy-dispersive spectroscopy \\
\hline & Risha Jasmine Nathan & FD & Film diffusion \\
\hline & nathan.rishajas@gmail.com & $\mathrm{Hg}$ & Mercury \\
\hline & Candace E. Martin & ICP-MS & Inductively coupled plasma-mass spectrometry \\
\hline & candace.martin@otago.ac.nz & $k_{1}$ & Rate constant for PFO \\
\hline & Dave Barr & $k_{2}$ & Rate constant for PSO \\
\hline & dbarr@chemistry.otago.ac.nz & $k_{\mathrm{FD}}$ & Rate constant for film diffusion \\
\hline \multirow[t]{2}{*}{1} & Pharmacology and Toxicology Department, University & $k_{\mathrm{PD}}$ & Rate constant for pore diffusion \\
\hline & of Otago, PO Box 56, Dunedin 9054, New Zealand & $\mathrm{m}$ & Weight of biosorbent \\
\hline \multirow[t]{2}{*}{2} & Geology Department, University of Otago, PO Box 56, & $\mathrm{Ni}$ & Nickel ion \\
\hline & Dunedin 9054, New Zealand & OP & Orange peel \\
\hline \multirow[t]{3}{*}{3} & Chemistry Department, Centre for Trace Element & $\mathrm{Pb}$ & Lead \\
\hline & Analysis, University of Otago, PO Box 56, Dunedin 9054, & PD & Pore diffusion \\
\hline & New Zealand & PFO & Pseudo-first order \\
\hline
\end{tabular}




$\begin{array}{ll}\text { PP } & \text { Potato peel } \\ \text { PSO } & \text { Pseudo-second order } \\ q_{\mathrm{e}} & \text { Equilibrium biosorption capacity } \\ q_{\mathrm{t}} & \text { Biosorption capacity at time ' } \mathrm{t} \text { ' } \\ R^{2} & \text { Correlation coefficient } \\ \mathrm{SA} & \text { Sodium alginate } \\ \mathrm{SE} & \text { Standard error of the mean } \\ \mathrm{SEM} & \text { Scanning electron microscopy } \\ T & \text { Contact time } \\ V & \text { Volume of solution }\end{array}$

\section{Introduction}

Contamination of drinking water and water quality issues are serious environmental concerns that presently affect 2.1 billion or more people globally according to United Nations Water Facts (UNESCO World Water Assessment Programme 2019). Among the major pollutants of drinking water, a range of metals and metalloids may be found at concentrations in the nanogram to microgram per litre range (Schwarzenbach et al. 2010). Biosorption methods for removal of metal and metalloid ions from drinking water have gained interest over the past few decades due to their lower costs, flexible design and ease of operation relative to traditional methods. Some of the most efficient biomolecules with the ability to complex metals in aqueous solutions include polysaccharides such as cellulose, starch, pectin and alginate (Crini 2005; Krishnani and Ayyappan 2006). The most abundant natural polysaccharides are found in plants (Lesmana et al. 2009; Schiewer and Iqbal 2010; Schiewer and Patil 2008b), and peel wastes from fruits and vegetables are a significant source of methane production when dumped in landfills (Chand and Pakade 2013). Therefore, a range of FVP wastes have been used as biosorbents for the removal of toxic ions from aqueous solutions (Jain 2015; Malik et al. 2016).

Alginate is an acidic polysaccharide that is found naturally in edible brown seaweeds (Phaeophyceae) and is used in various food industries as a thickener, gel producer and for stabilising emulsions (King 1983). The anionic nature of the alginate enables it to bind metal ions from solution and is a good option for use as a biosorbent because of its large availability, biodegradability, mechanical stability and low density (Banerjee et al. 2018; Wang et al. 2016a). Alginate may also be used for immobilising fine peel particles which are otherwise difficult to separate from water post biosorption (Jakóbik-Kolon et al. 2017; Wang et al. 2019).

Biosorption is complicated in the presence of multiple ions as there are ion-ion interactions taking place in addition to the surface interactions with the biosorbent (Mohan and Chander 2001). In this study, we have explored the biosorption potential of peels from banana (BP), orange (OP) and potato (PP) immobilised on sodium alginate (SA) beads to simultaneously remove seven toxic ions $(\mathrm{As}, \mathrm{Cd}, \mathrm{Cr}, \mathrm{Cu}, \mathrm{Hg}$, $\mathrm{Pb}$ and $\mathrm{Ni}$ ) at concentrations close to those found in contaminated drinking water. The chemical composition of three peels is given in Table 1. The advantage of using these peels is the utilisation of waste products from the food and agricultural industry. Such by-products of agricultural production have immense potential to be used in sustainable water treatment projects. On the other hand, the small requirement of FVPs in the manufacture of biosorbent beads may not be able to balance the huge amount of peels generated which is a major concern. Nonetheless, efforts have been made to study the biosorption potential of these FVPs.

In the present work, scanning electron microscopy coupled with energy-dispersive spectroscopy (SEM-EDS) was used to visualise the variation in surface structures of the beads that may affect their biosorption efficiencies. Experiments were performed at various drinking water $\mathrm{pH}$ values, and biosorption kinetic data were assessed using five standard models, namely film diffusion (FD), pore diffusion (PD), pseudo-first order (PFO), pseudo-second order (PSO) and Elovich equation. The performance of the SA bead with and without immobilised peel was studied, and the effect of increasing biosorbent concentration was investigated using FVP beads.
Table 1 Chemical composition of FVPs

\begin{tabular}{llll}
\hline Composition & Banana peel & Orange peel & Potato peel \\
\hline Cellulose, \% & 8.4 & 9.2 & 12 \\
Fat, \% & 1.7 & 0.8 & 0 \\
Proteins, \% & 8.3 & 8.1 & 8.3 \\
Starch, \% & 1.2 & 3.8 & 7.8 \\
Total sugar, \% & 29 & 46.2 & 17 \\
Vitamin C, \% & 1.9 & 0.1 & 5 \\
Reference & Emaga et al. (2007) & López, (2010) & Augustin et al. (1979) \\
& Mohapatra et al. (2010) & M'hiri, (2015) & Camire et al. (1997) \\
& Mosa and Khalil (2015) & Witczak et al. (2017) & Sepelev and Galoburda (2015) \\
& & & Toma et al. (1979) \\
\hline
\end{tabular}




\section{Materials and methods}

\section{Cocktail solution}

A cocktail solution of seven ions was prepared by spiking standard solutions of $\mathrm{As}(\mathrm{V}), \mathrm{Cd}(\mathrm{II}), \mathrm{Cr}(\mathrm{VI}), \mathrm{Cu}(\mathrm{II}), \mathrm{Hg}(\mathrm{II})$, $\mathrm{Pb}$ (II) and $\mathrm{Ni}$ (II) each at the same initial ion concentration $0.1 \mathrm{mgL}^{-1}$ for surface imaging, $\mathrm{pH}$ and kinetic studies. For studying the effect of bead number on biosorption, cocktail solutions were prepared by spiking all seven ions at initial concentration of $1 \mathrm{mgL}^{-1}$. The $\mathrm{pH}$ of the solution was adjusted using $0.1 \mathrm{M}$ nitric acid and $0.1 \mathrm{M}$ sodium hydroxide.

\section{Biosorbent preparation}

Biosorbent beads were prepared from BP, OP and PP according to the methods published in our earlier work with apple and cucumber peel beads (AP and CP, respectively) (Singh et al. 2019a, 2019b). BP, OP and PP were washed once with hot water, twice with tap water and twice with deionised distilled water, dried, pulverised and sieved to particle size $<240 \mu \mathrm{m}$. The peel particles were mixed with SA slurry and dropped in $0.1 \mathrm{M}$ calcium chloride solution. The beads formed were cured in the solution overnight, washed with deionised water to remove excess solution and dried. The dried beads were stored in a desiccator.

\section{Surface imaging}

The beads were analysed for changes in surface morphology before and after biosorption using SEM-EDS. The samples were mounted on an aluminium stub using double-sided carbon tape and sputter coated with $10 \mathrm{~nm}$ of gold palladium using an Emitech K575x sputter coater (EM Technologies Ltd, Kent, England). The surface morphology was examined using a JEOL 6700F Field emission SEM (JSM-6700F, JEOL Ltd., Japan) at $3.0 \mathrm{kV}$. Samples for EDS were coated with $10 \mathrm{~nm}$ of carbon using an Emitech 250X carbon coater attachment on the sputter coater. EDS analysis was performed using a JEOL 2300F EDS system (JEOL Ltd, Tokyo, Japan) at $20.0 \mathrm{kV}$.

\section{Experimental procedure}

Batch biosorption experiments were performed for all three bead types under identical conditions. One biosorbent bead was added to $25 \mathrm{~mL}$ of cocktail solution incubated at $25{ }^{\circ} \mathrm{C}$ in an orbital shaker set at $250 \mathrm{rpm}$. To examine the effect of changes in $\mathrm{pH}$, initial $\mathrm{pH}$ ranges of 6.5-8.5 were incubated for $24 \mathrm{~h}$. For kinetic studies, the cocktail solutions at $\mathrm{pH} 7.0$ were incubated over the time-frame of $15 \mathrm{~min}-72 \mathrm{~h}$.

\section{Concentration measurement, calculations and statistics}

At the end of each experiment, the beads were removed and the solutions were acidified and diluted with $2 \%$ nitric acid before injecting in an Agilent 7900 quadrupole inductively coupled plasma coupled with mass spectrometry (ICP-MS). A general purpose tune was selected for robust conditions to minimise interferences and instrumental drift. A multi-ion of six reference elements was added online to compensate for any drift or possible matrix effects. The instrument was calibrated using NIST traceable ICP-MS standards.

All experiments were performed in triplicate and the mean of the results along with the standard errors of the mean was used for calculations using the equations given in Table 2 . For statistical analysis of the data, a one-way analysis of

Table 2 Equations used for calculations

\begin{tabular}{lll}
\hline Concentration biosorbed: & $c_{\mathrm{ad}}=c_{0}-c_{\mathrm{t}}$ & (Singh et al. 2019b) \\
Biosorption percentage: & Biosorption $\%=\frac{c_{\mathrm{ad}}}{c_{0}} X 100$ & (Singh et al. 2019b) \\
Biosorption capacity: & $q_{\mathrm{t}}=\frac{c_{\mathrm{ad}}}{m} \cdot \frac{V}{1000}$ & (Singh et al. 2019b) \\
Film diffusion (FD) kinetics: & $\ln (-F)=-k_{\mathrm{FD}} t$ & (Gupta and Bhattacharyya 2011) \\
Pore diffusion (PD)-Weber-Morris kinetics: & $q_{\mathrm{t}}=k_{\mathrm{PD}} t^{0.5}$ & (Gupta and Bhattacharyya 2011) \\
Pseudo-first-order (PFO) kinetics: & $\ln \left(q_{\mathrm{e}}-q_{\mathrm{t}}\right)=\ln q_{\mathrm{e}}-k_{1} t$ & (Gupta and Bhattacharyya 2011) \\
Pseudo-second-order (PSO) kinetics: & $\frac{t}{q_{\mathrm{t}}}=\frac{1}{k_{2} q_{\mathrm{e}}^{2}}+\frac{t}{q_{\mathrm{e}}}$ & (Tan and Hameed 2017) \\
Initial biosorption rate: & $h=\frac{\mathrm{d} q}{\mathrm{~d} t}=k_{2}\left(q_{\mathrm{e}}\right)^{2}$ & (Tan and Hameed 2017) \\
Elovich equation kinetics: & $q_{\mathrm{t}}=a+b \ln t$ & (Schwantes 2016) \\
\hline
\end{tabular}

$c_{\mathrm{o}}=$ initial concentration $\left(\mathrm{mgL}^{-1}\right), c_{\mathrm{t}}=$ concentration at time ' $t$ ' $\left(\mathrm{mgL}^{-1}\right), q_{\mathrm{t}}=$ biosorption capacity at time ' $t$ ' $\left(\mathrm{mgg}^{-1}\right), m=$ mass of biosorbent $(g), V=$ volume of solution $(\mathrm{mL}), K_{\mathrm{FD}}=$ film diffusion rate constant $\left(\mathrm{min}^{-1}\right) ; q_{\mathrm{e}}=$ Biosorption capacity $\left(\mathrm{mg} \mathrm{g}^{-1}\right)$ at equilibrium; $K_{\mathrm{PD}}=$ pore diffusion rate constant $\left(\mathrm{mgg}^{-1} \mathrm{~min}^{-0.5}\right) ; K_{1}=$ pseudo-first-order rate constant $\left(\mathrm{min}^{-1}\right) ; K_{2}=$ pseudo-second-order rate constant $\left(\mathrm{gmg}^{-1} \mathrm{~min}^{-1}\right) ; h=\mathrm{ini}$ tial biosorption rate $\left(\mathrm{mgg}^{-1} \mathrm{~min}^{-1}\right) ; a=$ Elovich constant indicating chemisorption initial rate $\left(\mathrm{mgg}^{-1} \mathrm{~min}^{-1}\right) ; b=$ number of adsorption surface sites related to the coverage extension and the activation energy of chemisorption $\left(\mathrm{gmg}^{-1}\right)$ 
variance (ANOVA) coupled with a Bonferroni post hoc test was used and $p<0.05$ was the minimum requirement for statistical difference. All results are expressed as the mean $\pm \mathrm{SE}$ of three experiments.

\section{Results and discussion}

\section{Surface imaging}

SEM-EDS was used to identify the morphological and topographical changes on the bead surface following biosorption.
The beads were spherical in shape with an approximate diameter $1.5 \mathrm{~mm}$ and had a heterogeneous distribution of folds throughout the surface. Similar observations were made in case of hydrous zirconium oxide immobilised alginate beads which had an average bead diameter was $\sim 2 \mathrm{~mm}$ (Kumar et al. 2018), and activated lemon peel immobilised alginate beads that had an average diameter of $\sim 3 \mathrm{~mm}$ (Aichour et al. 2018). However, the beads differed in weight and size and therefore, their biosorption capacities were non-comparable.

SEM results at 50X and 2000X before biosorption revealed the presence of hills and valleys (Fig. 1). Among
SEM before biosoprtion

(a)

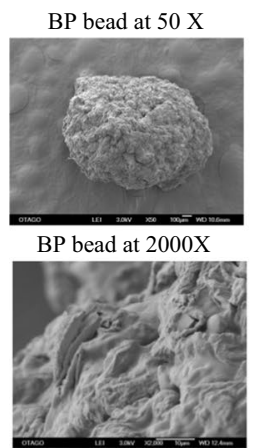

(b)

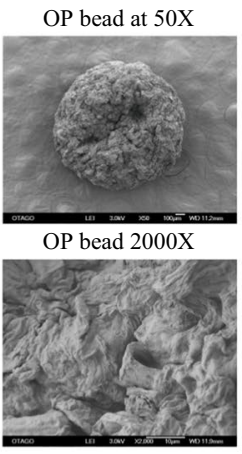

(c)

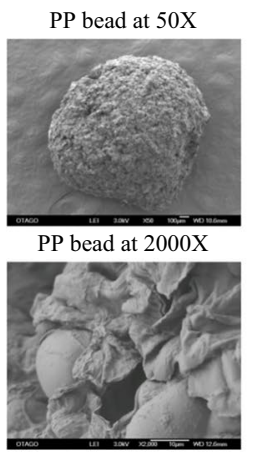

EDS before biosorption
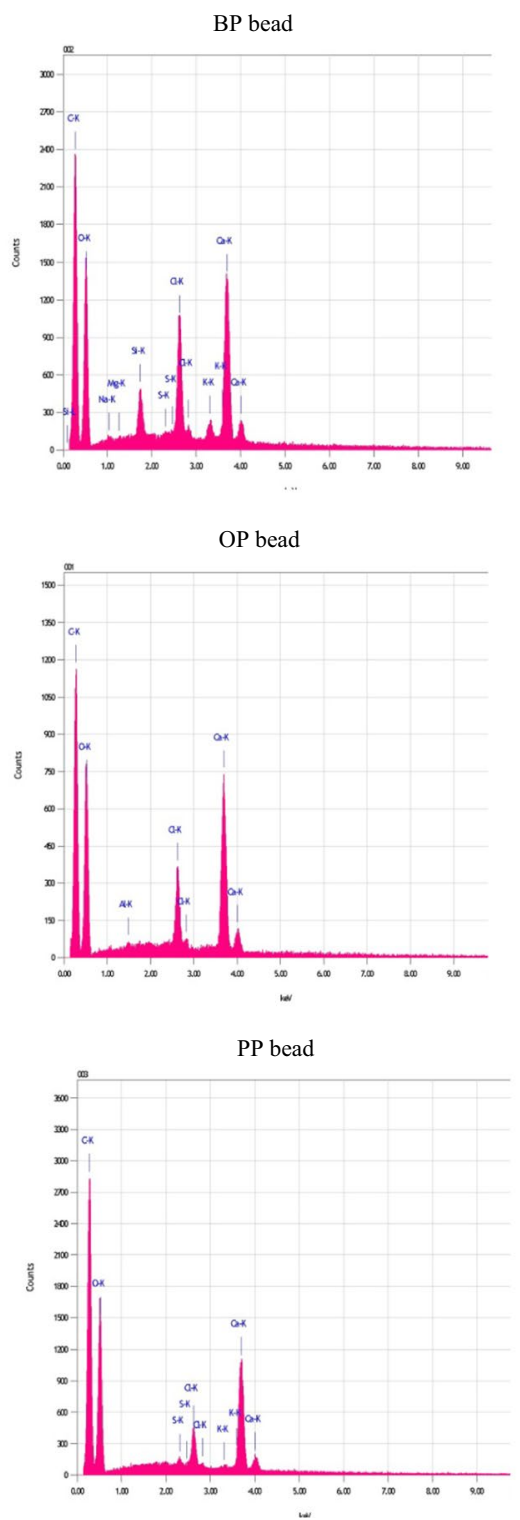

SEM after biosoprtion
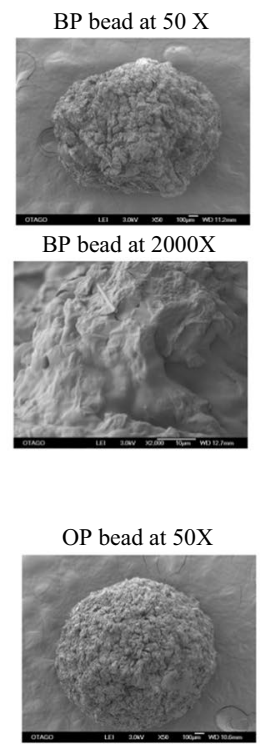

OP bead 2000X

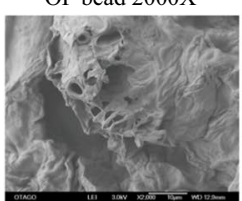

$\mathrm{PP}$ bead at $50 \mathrm{X}$

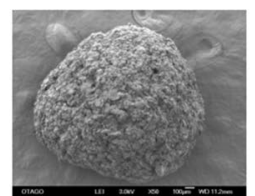

PP bead at $2000 \mathrm{X}$

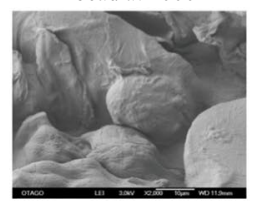

EDS after biosorption
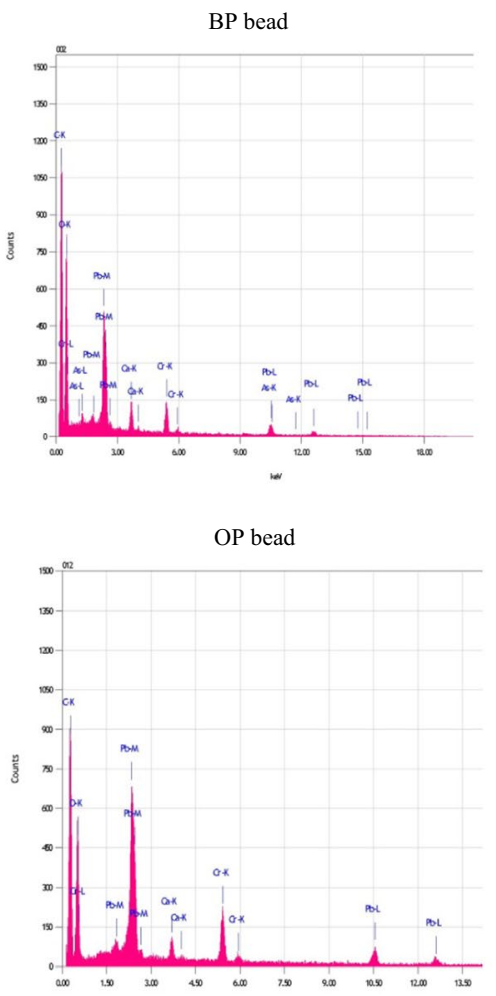

PP bead

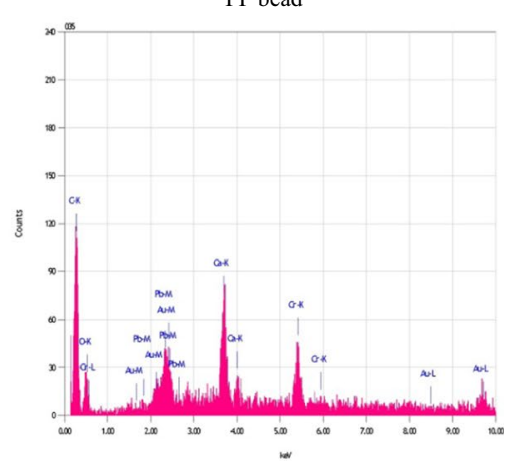

Fig. 1 SEM-EDS of FVP beads before and after biosorption. One bead was incubated in a cocktail solution containing all seven ions each at 0.1 mgL-1, $\mathrm{pH} 7.0,25^{\circ} \mathrm{C}$ with continuous shaking at $250 \mathrm{rpm}$ for $10 \mathrm{~h}$. a BP bead, b OP bead and $\mathbf{c} \mathrm{PP}$ bead 
the three beads, the surface of BP bead appeared to be most highly folded followed by OP bead. These folds formed cracks and pores of various sizes throughout the entire surface. The surface of PP bead on the other hand was the smoothest and was made of smooth ball-like structures that were embedded among the folds forming few or no gaps on the surface. EDS analysis did not show the presence of the spiked ions on the surface of any of the beads (Table 3).

The beads were incubated in a cocktail solution of seven ions for $10 \mathrm{~h}$, removed from solution and dried again. Zhang et al. have reported that the presence of a heterogeneous surface can be advantageous as it can expand to accommodate more ions (Zhang et al. 2018) and this has been demonstrated in the biosorption of $\mathrm{Cd}$ and $\mathrm{Pb}$ by waste tea leaves (Shrestha et al. 2013). This was also observed at 50 $X$, where the beads appeared swollen and were larger. While BP and OP beads were swollen by $\sim 20 \%$, there was negligible swelling $(<5 \%)$ in PP bead (Table 3$)$. A closer view at $2000 \mathrm{X}$ revealed the surface was more compact with partially or completely closed pores due to the relaxing of folds (Fig. 1). Similar observation was made in the biosorption of $\mathrm{Cu}$ by alga (Pouya and Behnam 2017) and methylene blue by carbon-alginate beads (Nasrullah et al. 2018) where the surface became more compact post biosorption. The surface of the beads became smoother after coming in contact with the ions. This was also reported in the biosorption of $\mathrm{Cr}$ by modified banana peel (Ali et al. 2016a) and multiple ions by tea wastes, maple leaves and mandarin peels (Abdolali, 2016) where the biosorbent surfaces became smoother as a result of entrapping of the ions in the pores. Similarly, BP and OP beads had a higher biosorption of ions compared to the smoother PP bead (Fig. 2). This may be because a highly folded surface is associated with higher biosorption capacity due to the increase in surface area (Wang et al. 2016b). This was also reported by Gerola et al. and Feng and Guo, where chemical modification of passion-fruit skin and orange peel, respectively, resulted in a rougher surface that yielded enhanced biosorption (Feng and Guo 2012; Gerola et al. 2013).

Sodium alginate has a unique property to form cross-linkages in the presence of multivalent cations such as calcium ions (Mohammadabadi and Javanbakht, 2020). In a study on alginate nanoparticles, the presence of calcium ions in the EDS spectra indicated the formation of cross-linkages between carboxylate ions in the polysaccharide and the divalent calcium ions (Geetha et al. 2015). In the present work, cross-linkages between polymeric chains by electrostatic interaction were evident in all the three FVP beads as indicated by their respective EDS spectra (Fig. 1, Table 3). Additionally, it is well known that the degree of crosslinking controls the level of water absorption by hydrogels and their capacity to take up and hold water (Pavithra et al. 2021). This swelling of hydrogels is because of the hydration of the hydrophilic groups of alginate (Ivánová et al. 2010). Among the three FVP beads studied, BP and OP beads had higher swelling than PP beads (Table 3 ). This is consistent with the ability of BP and OP beads to biosorb higher amount of heavy metals from cocktail solution (Fig. 2). Similar observations were made in the study of dry and gel calcium alginate beads where the gel beads demonstrated a higher amount of swelling by accommodating more water molecules and showed a faster removal of copper ions from solution (Ivánová et al. 2010). Thus, both a highly folded structure and the degree of cross-linkages in the polymeric

Table 3 Summary of SEM-EDS analysis of the beads

\begin{tabular}{llllll}
\hline Bead & $\begin{array}{l}\text { Weight of bead before } \\
\text { biosorption }(\mathrm{mg})\end{array}$ & $\begin{array}{l}\text { Size before biosorp- } \\
\text { tion }(\mu \mathrm{m} \times \mu \mathrm{m})\end{array}$ & $\begin{array}{l}\text { Size after biosorp- } \\
\text { tion }(\mu \mathrm{m} \times \mu \mathrm{m})\end{array}$ & $\begin{array}{l}\text { EDS elements before biosorption } \\
\begin{array}{l}\text { Additional EDS ele- } \\
\text { ments after biosorp- } \\
\text { tion }\end{array}\end{array}$ \\
\hline $\mathrm{BP}$ & $2.50 \pm 0.05$ & $1522 \times 1282$ & $1658 \times 1564$ & $\mathrm{C}, \mathrm{O}, \mathrm{K}, \mathrm{Na}, \mathrm{Ca}, \mathrm{Mg}, \mathrm{Si}, \mathrm{P}, \mathrm{S}, \mathrm{Cl}$ & $\mathrm{As}, \mathrm{Cr}, \mathrm{Hg}, \mathrm{Pb}$ \\
OP & $1.00 \pm 0.02$ & $1395 \times 1339$ & $1699 \times 1609$ & $\mathrm{C}, \mathrm{O}, \mathrm{K}, \mathrm{Na}, \mathrm{Ca}, \mathrm{Al}, \mathrm{Cl}$ & $\mathrm{Cr}, \mathrm{Cu}, \mathrm{Pb}$ \\
PP & $2.00 \pm 0.05$ & $1699 \times 1612$ & $1778 \times 1642$ & $\mathrm{C}, \mathrm{O}, \mathrm{K}, \mathrm{Ca}, \mathrm{Al}, \mathrm{S}, \mathrm{Cl}$ & $\mathrm{Cr}, \mathrm{Pb}$ \\
\hline
\end{tabular}

One bead was incubated in a cocktail solution containing all seven ions each at $0.1 \mathrm{mgL}^{-1}, \mathrm{pH} 7.0,25^{\circ} \mathrm{C}$ with continuous shaking at $250 \mathrm{rpm}$ for $10 \mathrm{~h}$

Fig. 2 Biosorption of ions. One bead was incubated in a cocktail solution containing all seven ions each at $0.1 \mathrm{mgL}-1$, pH 7.0, $25^{\circ} \mathrm{C}$ with continuous shaking at $250 \mathrm{rpm}$ for $10 \mathrm{~h}$. a BP bead, b OP bead and $\mathbf{c}$ PP bead (a) BP bead

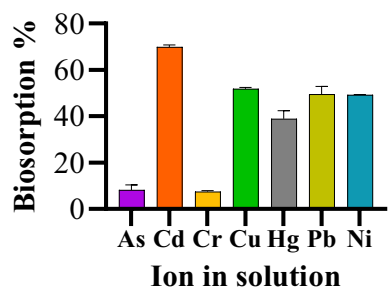

(b) OP bead

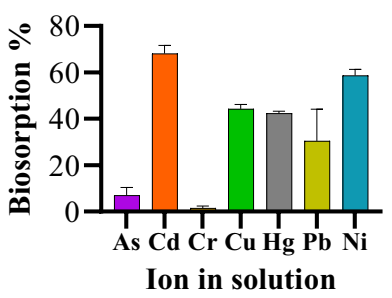

(c) PP bead

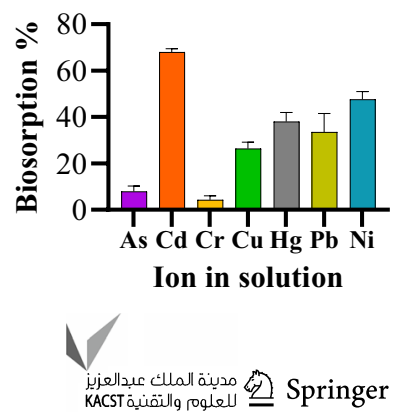


alginate complex are responsible for the increased ability of FVP beads to take up metal ions from solution.

The simultaneous removal of ions from solution by the three beads was compared and the ICP-MS results (Fig. 2) were compared with the EDS results. While the EDS spectra showed prominent peaks of $\mathrm{As}, \mathrm{Cr}, \mathrm{Cu}, \mathrm{Hg}$ and $\mathrm{Pb}$ post biosorption (Table 3), Cd was missing from the EDS spectra even though the biosorption of $\mathrm{Cd}$ was among the highest for all beads (Fig. 2). Cu was found in the spectra of only OP beads, although BP had a higher biosorption of this ion. Similarly, $\mathrm{Hg}$ was absent from the spectra of OP and PP beads although the biosorption of $\mathrm{Hg}$ by these beads was similar. Ni was absent from all the three beads although there was significant biosorption of this ion. In contrast, As and $\mathrm{Cr}$ anions had significantly smaller biosorption but were identified in the spectra of the beads. This suggests that these may have stacked on the previously biosorbed divalent ions such as $\mathrm{Cu}, \mathrm{Hg}$ and $\mathrm{Pb}$ because of the unsuitability of the biosorbent surface for the binding of these anions. In contrast, the ions with high biosorption such as $\mathrm{Cd}$ and $\mathrm{Ni}$ may have penetrated the biosorbent surface through the pores present. Similar findings were reported in our earlier work with AP and CP beads (Singh et al. 2019a, 2019b).

\section{Effect of initial pH}

The $\mathrm{pH}$ of the solution is an important parameter that influences the biosorption of ions. To determine the effect water $\mathrm{pH}$, but still remain in the acceptable range for drinking water, BP, OP and PP beads were incubated in cocktail solutions at $\mathrm{pH}$ values between 6.5 and 8.5 . The results showed that the biosorption capacity of $\mathrm{Pb}$ was most significantly affected among all the seven ions. It increased significantly at $\mathrm{pH} 7.5$ and 8.0 for all three bead types compared to a $\mathrm{pH}$ of 7.0 (Fig. 3). We reported a similar significant $\mathrm{pH}$-dependent effect for $\mathrm{Pb}$ with $\mathrm{AP}$ beads (Singh et al. 2019a). Optimal biosorption of $\mathrm{Pb}$ at pH 8.0 was also demonstrated for potato peel biomass by Kajjumba et al. (2018). In contrast, the biosorption capacity of $\mathrm{Cd}$ and $\mathrm{Ni}$ significantly decreased at $\mathrm{pH} 7.5$ for $\mathrm{OP}$ beads, and of Cd at pH 8.0 for PP beads (Fig. $3 b$ and c). In contrast, Kajjumba et al. (2018) also reported that $\mathrm{pH}$ 8.0 was ideal for the biosorption of $\mathrm{Cd}$ by potato peel biomass. This may be because of the increased complexity of multi-ion biosorption where the ions were competing for the same binding sites on the surface of the beads. A decrease in the biosorption of $\mathrm{Cd}$ and $\mathrm{Ni}$ may have occurred due to the formation of hydroxyl complexes (Beidokhti et al. 2019; Boparai et al. 2013; Ciesielczyk et al. 2013; Mohamed et al. 2019; Park et al. 2017; Van Thuan et al. 2017) at more basic pH. Additionally, the mobility of these ion complexes may be limited thus lowering their diffusion through the liquid film and/or pores of the beads (Cozmuta et al. 2012). Similarly, a significant decrease in the biosorption capacity of BP and OP beads was observed for $\mathrm{Cu}$ and $\mathrm{Hg}$ ions at $\mathrm{pH} 8.0$ and 8.5 (Fig. 3a and b). This could also be the result of precipitation of $\mathrm{Cu}(\mathrm{OH})_{2}$ and $\mathrm{Hg}(\mathrm{OH})_{2}$ that has been reported when water $\mathrm{pH}$ is greater than 5.0 (Deng et al. 2015; Raza et al. 2015). In fact, neutral $\mathrm{pH}$ has been reported as optimum for $\mathrm{Cu}$ biosorption by Pinus sawdust (Semerjian 2018). Overall, the results for $\mathrm{Cu}, \mathrm{Hg}, \mathrm{Pb}$ and $\mathrm{Ni}$ biosorption by BP, OP and PP beads are
Fig. 3 Effect of $\mathrm{pH}$ on bead biosorption capacity. One bead was incubated in a cocktail solution of all seven ions each at $0.1 \mathrm{mgL}-1,25{ }^{\circ} \mathrm{C}$ with continuous shaking at $250 \mathrm{rpm}$ for $24 \mathrm{~h}$ The initial $\mathrm{pH}$ of each solution was adjusted to the specified $\mathrm{pH}$ at the start of the experiment. The points represent mean $\pm \mathrm{SE}$ for $N=3$. Statistical significance was calculated based on a oneway ANOVA with Bonferroni post hoc test, *Significantly different compared to $\mathrm{pH} 7.0$, $p<0.05$. a BP bead, b OP bead and $\mathbf{c} \mathrm{PP}$ bead

\section{(a) BP bead}

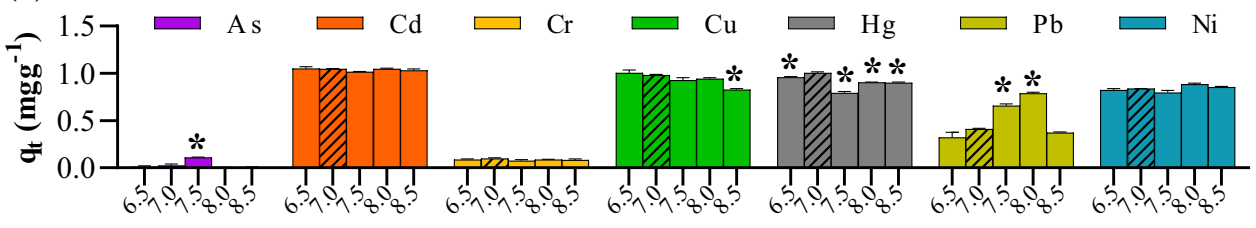

(b) OP bead

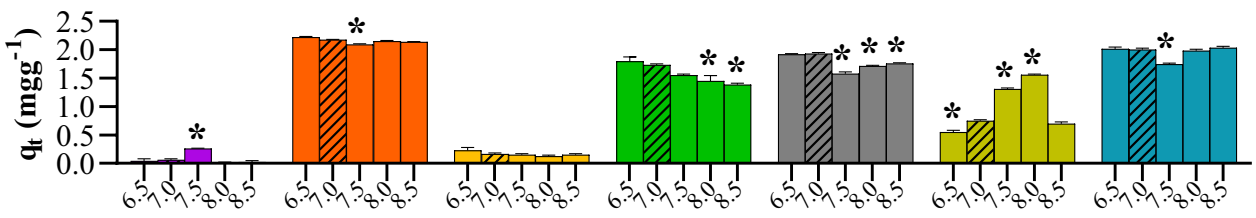

(c) PP bead

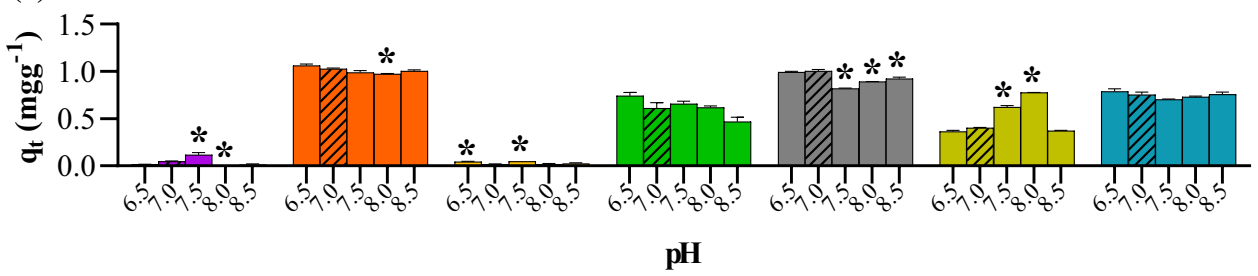


similar to our results for $\mathrm{CP}$ bead biosorption of these ions from an identical cocktail solution (Singh et al. 2019b).

The ions with the lowest biosorption were As and $\mathrm{Cr}$. This was expected because As adsorption is high in strongly acidic $\mathrm{pH}$ where the biosorbent surface is more protonated thus allowing feasible uptake of arsenate anion from solution. In contrast, at higher $\mathrm{pH}$ values the biosorbent becomes more negatively charged and therefore repels the negatively charged species (Jung et al. 2017; Vu et al. 2017). In contrast, since $\mathrm{Cr}$ is an amphoteric metal (Thakur et al. 2015), there was no variation in the biosorption capacity with changes in $\mathrm{pH}$ for $\mathrm{Cr}$, except for PP bead where it significantly increased at 6.5 and 8.5 compared to neutral $\mathrm{pH}$ (Fig. 3c). In contrast to the biosorption capacity of these anions, that of the metal ions was low at acidic $\mathrm{pH}$, due to the higher availability of hydrogen ions that compete for binding to surface functional groups (Kakalanga et al. 2012). Additionally, deprotonation of surface functional groups at acidic $\mathrm{pH}$ impairs the ability of the biosorbent surface to bind metal cations (RomeroGonzález et al. 2001). Thus, the simultaneous removal of both cations and anions from drinking water is challenging and requires more research.

\section{Effect of contact time and biosorption kinetics}

To study the biosorption trend with time and determine the equilibrium time for the various ions, BP, OP and PP beads were incubated with a cocktail solution of 7 ions for $15 \mathrm{~min}-72 \mathrm{~h}$. The results showed that there was a faster initial biosorption phase followed by a slower rate of removal of the ions (Fig. 4). This is directly related to the availability of the binding sites on the bead surface that were rapidly occupied by the ions in the initial phase. As the reaction approached equilibrium, biosorption slowed and biosorption percentage decreased due to the decrease in the ion concentration in solution (Akkaya and Güzel 2013; Iqbal et al. 2009b; Iqbal et al. 2009c). The ion with the shortest equilibrium time and the highest biosorption percentage was $\mathrm{Cd}$, followed by $\mathrm{Cu}, \mathrm{Hg}$ and $\mathrm{Ni}$ (Table 4). PP bead was the slowest in the uptake of $\mathrm{Cu}$ which did not reach equilibrium within $72 \mathrm{~h}$ (Fig. 4). Similar behaviour of $\mathrm{Cu}$ ions was observed with $\mathrm{CP}$ bead in our previous work, where the ion had not reached equilibrium within $72 \mathrm{~h}$ (Singh et al. 2019b). This suggests that surfaces of CP and PP beads were not suitable for the competitive binding of $\mathrm{Cu}$ relative to the other ions.

A deeper investigation into the kinetics of biosorption by BP, OP and PP immobilised beads was made at four time points and a comparison was made with SA beads. A significantly enhanced biosorption was observed with FVP beads especially in the initial phase of biosorption (Fig. 5). By $24 \mathrm{~h}$, biosorption by SA bead became closer to the uptake of ions by FVP beads. Similar results were obtained with identical experiments comparing AP beads and SA beads (Singh et al. 2019a). Thus, immobilising AP, BP, OP and PP peels on SA shortened the equilibrium time and significantly increased the biosorption percentage of ions from a cocktail solution.

Biosorption kinetics determine the rate at which the process occurs and are influenced by the properties of the bead and the ions in solution. Among the most popular are linearised diffusion models such as FD and PD, and surface attachment models such as PFO, PSO and Elovich equation. (Kajjumba et al. 2018). Data generated with BP, OP and PP beads were modelled using these models and the suitability of each model was determined by the goodness of fit calculated by $\mathrm{R}^{2}$ values.

\section{Film and pore diffusion kinetics}

According to the FD model, the ions must overcome the hydrodynamic layer resistance in order to penetrate the liquid film surrounding the bead and the rate of reaction is determined by the distance the ions need to travel to reach the bead surface, the thickness of the boundary layer and the velocity of the bulk solution (Sahmoune 2018). Among the ions that fit this model well, the diffusion of $\mathrm{Cd}$ was the highest on BP and PP beads, whereas $\mathrm{Hg}$ was the fastest on (a) BP bead

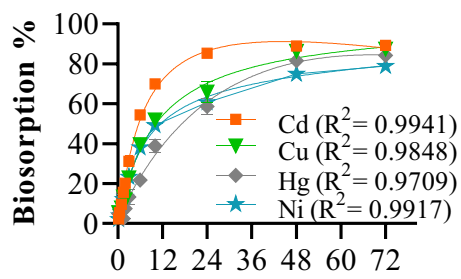

t (h) (b) OP bead

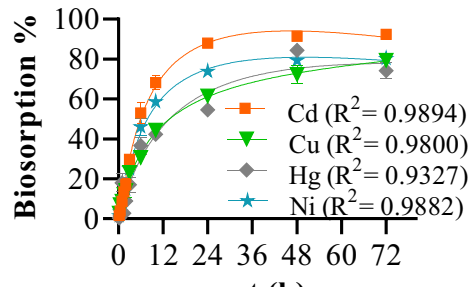

t (h) (c) PP bead

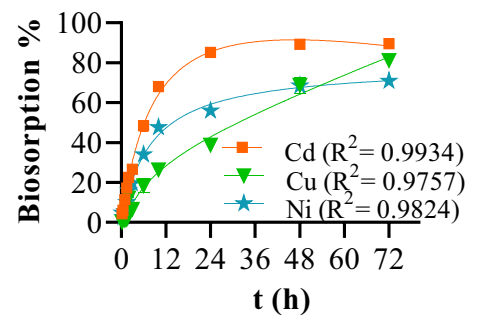

Fig. 4 Effect of contact time on biosorption. One bead was incubated in a cocktail solution containing all seven ions each at $0.1 \mathrm{mgL}-1, \mathrm{pH}$ $7.0,25{ }^{\circ} \mathrm{C}$ with continuous shaking at $250 \mathrm{rpm}$ for $15 \mathrm{~min}-72 \mathrm{~h}$. The points represent mean \pm SE for $N=3$ with data analysis by nonlinear regression where $R^{2}>0.93$. a BP bead, $\mathbf{b}$ OP bead and $\mathbf{g}$ PP bead 
Table 4 Biosorption kinetic parameters
Fig. 5 Temporal biosorption of FVP and SA beads. One bead was incubated in a cocktail solution containing all seven ions each at $0.1 \mathrm{mgL}-1, \mathrm{pH} 7.0$, $25{ }^{\circ} \mathrm{C}$ with continuous shaking at $250 \mathrm{rpm}$ for $15 \mathrm{~min}-72 \mathrm{~h}$. *Significantly different biosorption compared to the corresponding SA bead, $\mathrm{p}<0.05$. The bars represent mean $\pm \mathrm{SE}$ for $N=3$; data analysis by oneway ANOVA with a Bonferroni post hoc test. a $1 \mathrm{~h}, \mathbf{b} 6 \mathrm{~h}, \mathbf{c} 24 \mathrm{~h}$ and $\mathbf{d} 72 \mathrm{~h}$

\begin{tabular}{lllll}
\hline Ion/ Parameter & $\mathrm{Cd}$ & $\mathrm{Cu}$ & $\mathrm{Hg}$ & $\mathrm{Ni}$ \\
\hline BP bead & & & & \\
Eq. time (h) & 24 & 48 & 48 & 48 \\
Max eq. bios\% & $89.3 \pm 1.2$ & $87.3 \pm 0.7$ & $84.2 \pm 1.5$ & $78.9 \pm 0.2$ \\
Max eq. bios. capacity $\left(\mathrm{mgg}^{-1}\right)$ & $1.02 \pm 0.01$ & $1.15 \pm 0.01$ & $0.39 \pm 0.01$ & $0.90 \pm 0.02$ \\
OP bead & & & & \\
Eq. time (h) & 24 & 48 & 48 & 24 \\
Max eq. bios\% & $92.4 \pm 0.4$ & $79.3 \pm 0.4$ & $84.4 \pm 1.0$ & $80.3 \pm 0.9$ \\
Max eq. bios. capacity (mgg & & & \\
PP bead & $2.11 \pm 0.01$ & $2.09 \pm 0.01$ & $0.78 \pm 0.01$ & \\
Eq. time (h) & & & & 48.04 \\
Max eq. bios\% & 24 & $* *$ & - & $70.9 \pm 1.7$ \\
Max eq. bios. capacity (mgg & & \\
\end{tabular}

One bead was incubated in a cocktail solution containing all seven ions each at $0.1 \mathrm{mgL}^{-1}, \mathrm{pH} 7.0,25^{\circ} \mathrm{C}$ with continuous shaking at $250 \mathrm{rpm}$ for $15 \mathrm{~min}-72 \mathrm{~h}$. Data presented for $N=3$. Only ions with $R^{2}>0.93$ are shown

**Did not reach equilibrium, data presented for the last time point in the experiment

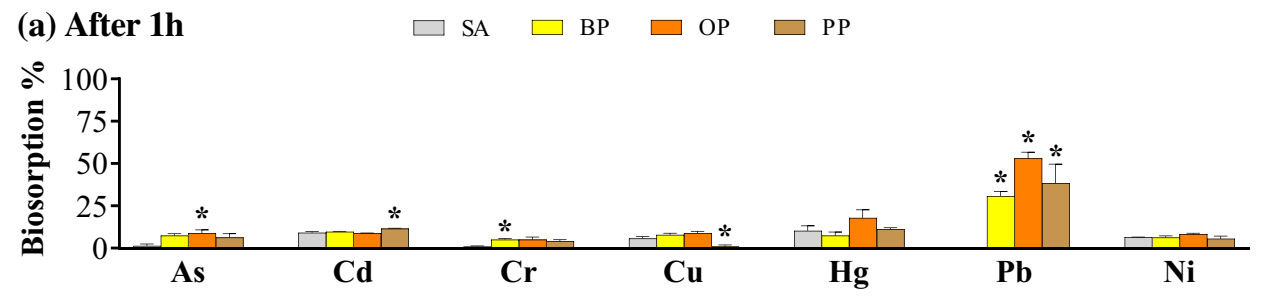

(b) After $6 \mathrm{~h}$

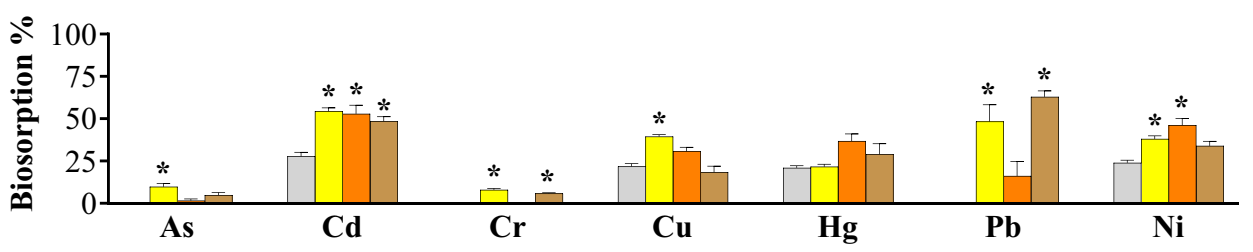

(c) After $24 \mathrm{~h}$

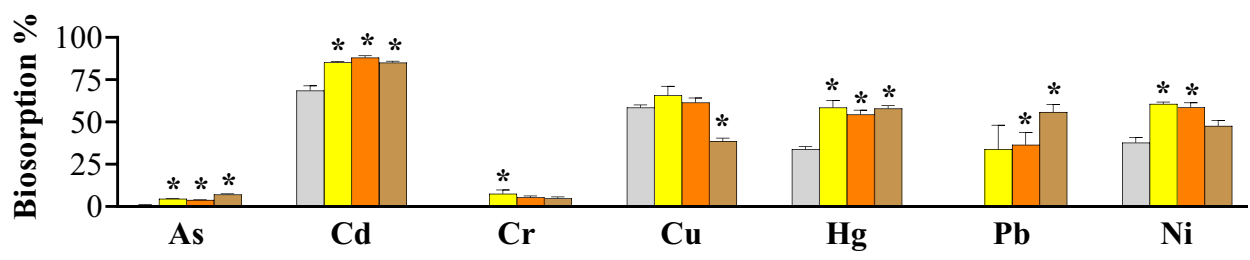

(d) After $72 \mathrm{~h}$

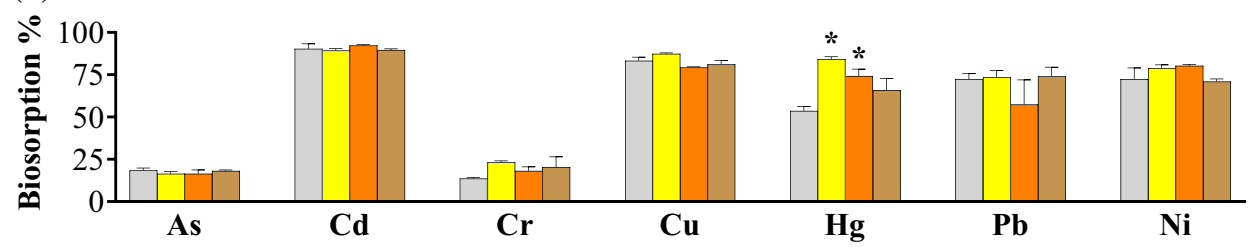

OP bead (Fig. 6, Table 5). In contrast, the PD-Weber-Morris model is based on the assumption that diffusion through the pores of the bead is the sole rate determining step in the reaction and thus, the straight line graph of the equation
(Table 2) must pass through the origin. Any deviation from this indicates that the biosorption reaction is also controlled by FD (Stavrinou et al. 2018). Cu and Ni biosorption by BP and OP beads fit both FD and PD models, thereby indicating 
(a) Film diffusion

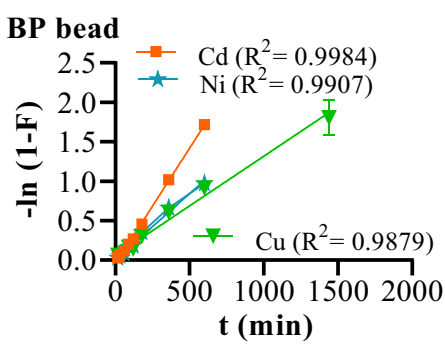

(b) Pore diffusion

\section{BP bead}

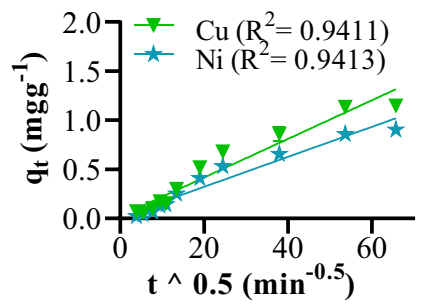

(c) Pseudo-first order

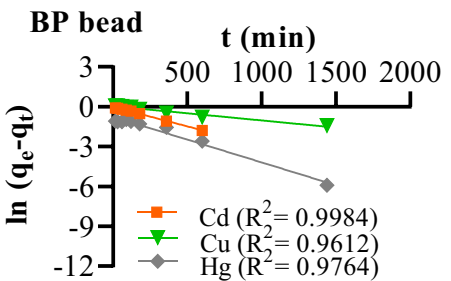

(d) Pseudo-second order
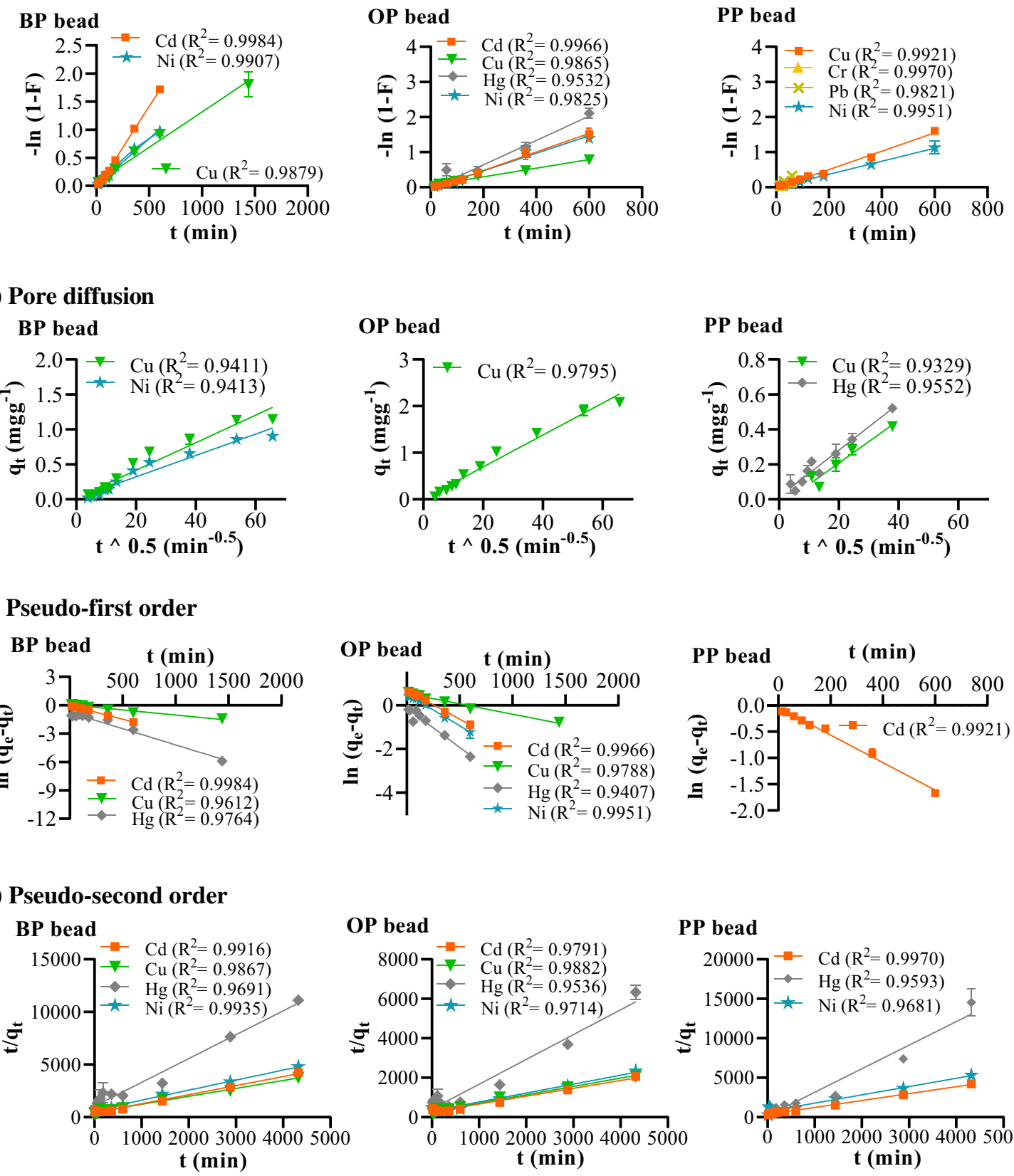

\section{PP bead}

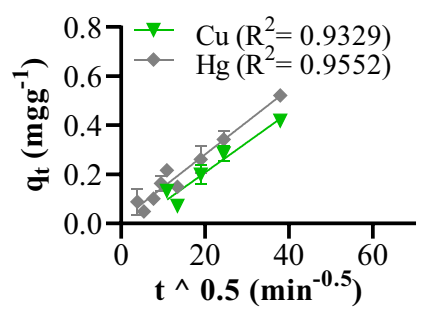

\section{PP bead t (min)}

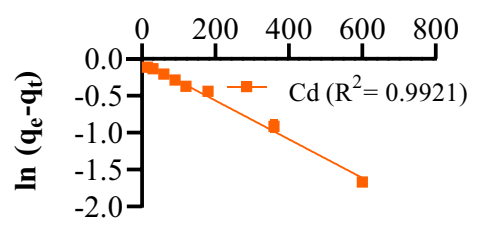

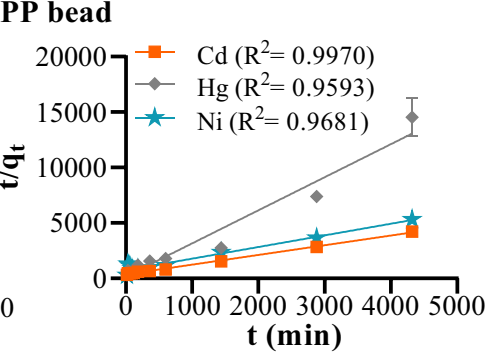

(e) Elovich equation

\section{BP bead}

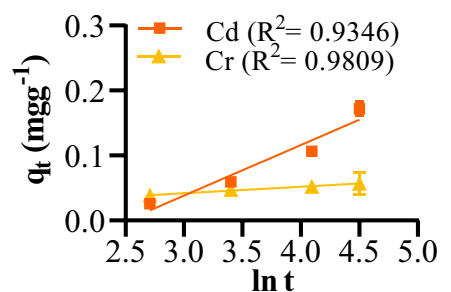

OP bead

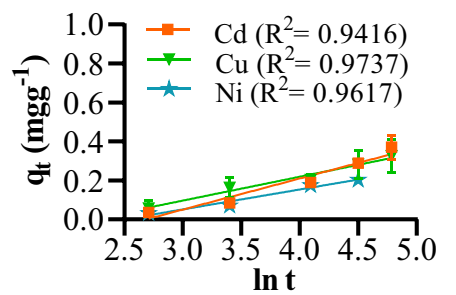

Fig. 6 Biosorption kinetic models. One bead was incubated in a cocktail solution containing all seven ions each at $0.1 \mathrm{mgL}-1, \mathrm{pH}$ $7.0,25{ }^{\circ} \mathrm{C}$ with continuous shaking at $250 \mathrm{rpm}$ for $15 \mathrm{~min}-72 \mathrm{~h}$.
The points represent mean \pm SE for $N=3$ with data analysis by linear regression. Only ions with an $R^{2}>0.93$ are shown. a FD, b PD, c $\mathrm{PFO}, \mathbf{d} \mathrm{PSO}$ and e Elovich equation 


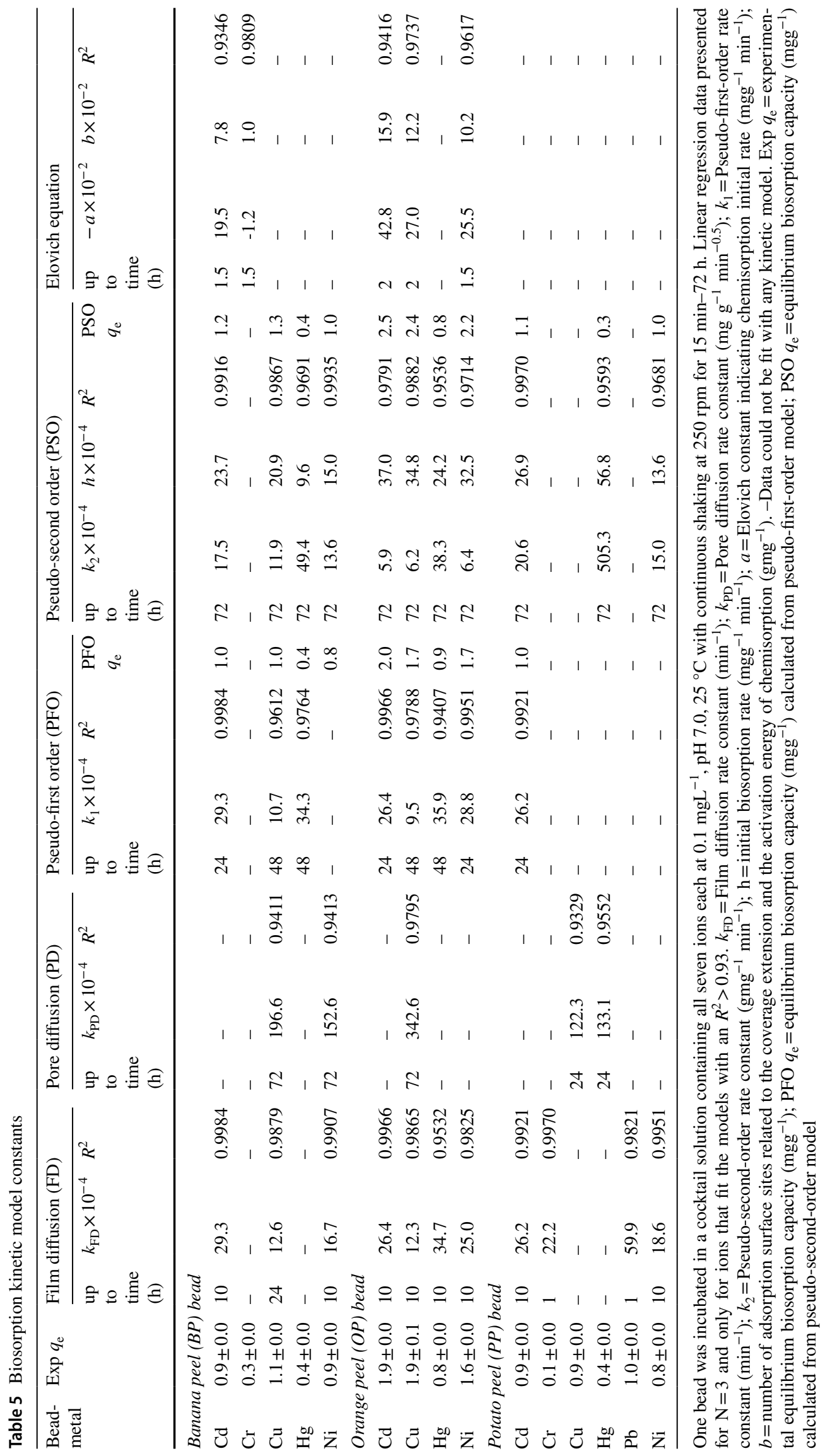


that both film and pore diffusions were contributing factors in determining the rate of the biosorption reaction. In contrast, $\mathrm{Cu}$ and $\mathrm{Hg}$ biosorption rate on PP bead was controlled by PD for up to $24 \mathrm{~h}$ (Fig. 6, Table 5). This confirms the assumption that heterogeneity of the surface is directly related to the performance of the biosorbent. The surface of the PP bead was the smoothest and appeared to be least porous, thus limiting the diffusion of the ions through its surface and increasing the equilibrium time (Fig. 1, Table 4).

\section{Pseudo-first and pseudo-second-order kinetics}

The PFO model given by Lagergren assumes that the rate of the biosorption reaction is directly proportional to the number of vacant binding sites on the surface of the biosorbent and is usually valid only for time periods where biosorption is fast (Ali et al. 2016b). However, it has been shown to be valid for both the initial phases as well as for longer biosorption times near equilibrium when the biosorbate is present at high enough concentrations (Mashkoor and Nasar 2019; Tan and Hameed 2017; Wang, 2018). This contradiction is a result of the uniqueness of the various biosorption systems used to test the validity of the model. While data for $\mathrm{Cd}$ and $\mathrm{Ni}$ were valid for $24 \mathrm{~h}$, that for $\mathrm{Cu}$ and $\mathrm{Hg}$ fit for up to $48 \mathrm{~h}$ in the PFO model (Table 5). In contrast, the PSO model given by Ho and McKay, assumes that the rate of reaction is proportional to the square of the number of vacant sites (Ali et al. 2016b).

While the PFO model considers mass transfer resistance and incorporates the role of both film and pore diffusions (Deng et al. 2015; Plazinski 2010), the PSO model assumes that surface attachment is the slowest step in the biosorption reaction and includes PD for explaining the rate determining mechanism (Deng et al. 2015; Plazinski et al. 2013). The FD model was only valid in the initial phase for all of three beads, whereas the PD, PFO and PSO models fit until equilibrium was reached. This suggests that while diffusion of ions was still occurring through the pores of the bead, surface attachment mechanisms also took over as the reaction progressed towards equilibrium. A good fitting to both PFO and PSO models also indicates the possibility of simultaneously occurring physisorption and chemisorption which has been reported in the biosorption of Orange 16 dye on activated carbon prepared from hemp stalks (Rehman 2017). This may be due to the stacking of ions physically on top of the first layer chemisorbed on the biosorbent surface. Similar observations were made for the uptake of $\mathrm{Cd}, \mathrm{Cu}$, $\mathrm{Pb}$ and $\mathrm{Ni}$ by modified Chitosan nanofiber membrane, where both PFO and PSO models were valid (Aliabadi et al. 2013). Similar to our findings with AP and CP beads (Singh et al. 2019a, 2019b), the experimental $q_{\mathrm{e}}$ values were closer to PFO $q_{\mathrm{e}}$ than PSO $q_{\mathrm{e}}$ (Table 5), thus confirming the better fit to the physisorption-based PFO model. The physisorption rate of $\mathrm{Cu}$ was the slowest, while that of $\mathrm{Hg}$ was the highest among all ions (Fig. 6c) and similar results were reported from our work with AP and CP beads.

\section{Elovich equation kinetics}

This is a chemisorption-based model that ignores the possibility of desorption or any interaction among ions (Gupta and Bhattacharyya 2011). Results from the modelling showed that the biosorption of $\mathrm{Cr}$ by BP bead was valid for the first $1.5 \mathrm{~h}$ with the highest $R^{2}$ value for this model (Table 5). Cr biosorption data were also reported to fit the Elovich equation with kaolinite (Gupta and Bhattacharyya 2011), suggesting the formation of chemical bonds between $\mathrm{Cr}$ and the biosorbent surface. However, similar to our previously reported worth with AP and CP beads (Singh et al. 2019a, 2019b), relatively low $R^{2}$ values were calculated for the biosorption of the other ions by BP, OP and PP beads. This validates the physical nature of ion interactions on the bead surface.

\section{Effect of biosorbent concentration}

To determine the change in biosorption with increase in bead number, one to ten BP beads were incubated in a cocktail solution of seven ions. BP beads were chosen for this study because they were more versatile and performed better overall, as compared to OP and PP. Since the number of binding sites is proportional to the number of beads, the concentration of the ions in solution decreased exponentially with an increase in bead number, with a corresponding logarithmic increase in the biosorption percentage (Fig. 7a and b). This is explained by the saturation of the binding sites at low biosorbent concentration because of the excessive number of ions present in solution (Paul et al. 2018). Furthermore, the bead to ion ratio decreases, thus decreasing the overall biosorption capacity at higher bead numbers. Additionally, with an increase in bead number, although the amount of biosorbed ions increased, the biosorbed ion-to-bead ratio actually decreased, due to the corresponding increase in total bead weight leading to an exponential decrease in biosorption capacity of $\mathrm{Cd}, \mathrm{Hg}$ and $\mathrm{Ni}$ ions (Fig. 7c). The curves tended to plateau at concentrations of 5-6 beads due to the saturation of the binding sites. A similar exponential decrease in ion concentration was previously demonstrated for AP bead (Singh et al. 2019a). Therefore, we compared the biosorption of $\mathrm{AP}$ and $\mathrm{BP}$ beads and the results indicated a significantly higher biosorption of $\mathrm{Cd}, \mathrm{Hg}$ and $\mathrm{Ni}$ ions even though the weight of BP bead was more than AP bead (Table 6). Thus, under identical environmental conditions, the simultaneous biosorption of heavy metals by BP bead was superior to AP bead. 


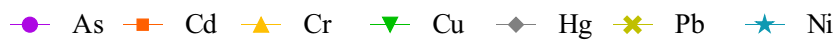

(a)

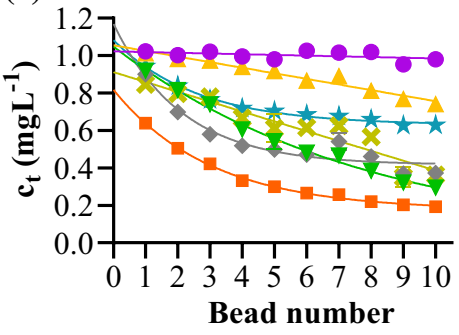

(b)

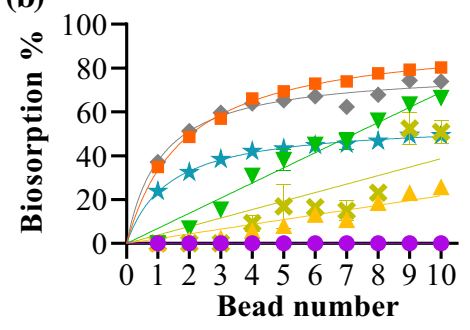

(c)

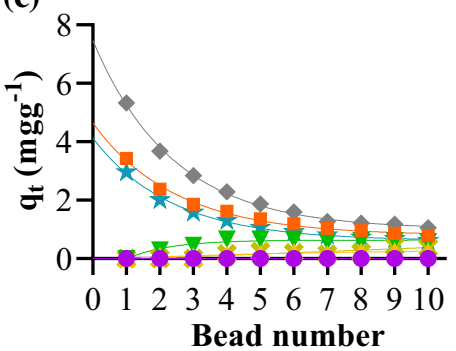

Fig. 7 Effect of an increase in bead number. One to ten beads were incubated in a cocktail solution containing all seven ions each at 1 $\mathrm{mgL}-1$ at $\mathrm{pH} 7.0,25^{\circ} \mathrm{C}$ with continuous shaking at $250 \mathrm{rpm}$ for $10 \mathrm{~h}$.
The points represent the mean \pm SE for $N=3$ with data analysis by nonlinear regression. a ion concentration, $\mathbf{b}$ biosorption percentage and $\mathbf{c}$ biosorption capacity
Table 6 FVP bead biosorbent concentration parameters

\begin{tabular}{lllll}
\hline Parameters & $\begin{array}{l}\text { Weight of } \\
\text { one bead } \\
(\mathrm{mg})\end{array}$ & $\mathrm{Cd}$ & $\mathrm{Hg}$ & $\mathrm{Ni}$ \\
\hline AP bead & $2.20 \pm 0.05$ & & & \\
Bios\% & & $27.4 \pm 0.7$ & $31.9 \pm 1.4$ & $20.0 \pm 0.7$ \\
$q_{\mathrm{t}}\left(\mathrm{mgg}^{-1}\right)$ & & $3.06 \pm 0.08$ & $5.20 \pm 0.23$ & $2.82 \pm 0.09$ \\
BP bead & $2.50 \pm 0.05$ & & & \\
Bios\% & & $34.9 \pm 0.1^{*}$ & $37.2 \pm 0.9 *$ & $23.9 \pm 0.3 *$ \\
$q_{\mathrm{t}}\left(\mathrm{mgg}^{-1}\right)$ & & $3.43 \pm 0.01$ & $5.33 \pm 0.13$ & $2.96 \pm 0.04$ \\
\hline
\end{tabular}

One bead in cocktail solution containing all seven ions each at 1 $\mathrm{mgL}^{-1}$ at $\mathrm{pH} 7.0,25^{\circ} \mathrm{C}$ with continuous shaking at $250 \mathrm{rpm}$ for $10 \mathrm{~h}$. Values represent the mean \pm SE for ${ }_{N}=3$. $*$ Significantly different to the corresponding value for AP bead, $p<0.05$

In our study with CP bead, we had established that biosorption was suppressed in the presence of multi-ion solutions compared to single ion solutions, and suppression was enhanced as the number of competing ions increased (Singh et al. 2019b). Additionally, low initial ion concentrations used in our experiments yielded significantly small biosorption capacities and this was also reported by Kurniawan et al. (2006). Unfavourable biosorption at low concentrations was demonstrated by El-Azazy et al. in their work on the biosorption of heavy metals by potato peel (El-Azazy et al. 2019). Lastly, while drinking water $\mathrm{pH}$ is not ideal for the optimum removal of toxic ions from solution, the biosorption capacities presented in our work are lower than those published by others.

\section{Conclusion}

Examination of bead surface morphology indicated that the degree of roughness and heterogeneity of the surface was directly related to the biosorption performance. Additionally, the degree of cross-linkages formed in the alginate polymeric complex indicated by the amount of swelling by the intake of water molecules in the FVP beads is also responsible for the increased assimilation of metal ions by the beads. $\mathrm{PP}$ bead was slower in the uptake of $\mathrm{Cu}$ and $\mathrm{Hg}$ ions as it was smoother and had the least amount of swelling among the three FVP beads. This limited the diffusion of these ions through the pores on the bead. The binding of the ions on the surface of BP, OP and PP beads was physical in nature and thus can potentially be recovered through desorption methods requiring low energy. Biosorption of the ions was $\mathrm{pH}-$ dependent but the beads were effective at all drinking water $\mathrm{pH}$ values for the removal of divalent cations. Although an increase in the number of BP beads in cocktail solution significantly increased the percentage of ions, it also significantly decreased their biosorption capacity. Thus, optimum values of biosorbent concentration must be determined for each biosorbent for cost-effective water treatment.

The physical and chemical properties of the beads, ions to be removed, solution matrix and the environmental conditions significantly influence biosorption, and each of these parameters is unique in the various published studies. Therefore, an accurate comparison of the biosorption kinetics can only be made when experiments are performed under identical conditions. Even though the biosorption capacities of BP, $\mathrm{OP}$ and PP beads are non-comparable with other biosorbents, the overall usefulness of these beads is shown by their ability to remove a high percentage of metals from solution. Furthermore, the advantage of immobilising the peels was the ability to easily remove them from water by decantation, as well as their significantly higher biosorption and smaller equilibrium times relative to SA beads. Thus, FVP beads have the potential to ultimately revolutionise the treatment of drinking water in developing countries.

The aim of this research was to highlight the usefulness of a waste product such as FVP to be employed as a potential biosorbent for the removal of heavy metals from 
drinking water. For this purpose, peels were collected from banana, orange and potato and immobilised on to alginate beads. A comparison of their structures and biosorption properties revealed the difference in their ability to take up heavy metals from solution under similar environmental conditions. The results of this experiment show that careful study of FVP bead surface characteristics can save both time and resources. The less useful biosorbent beads can be removed in the initial stages of screening as valuable information can be collected just by studying the structure of the biosorbents before batch biosorption experiments are performed. In this study, unmodified peels from potato have proven to be the least useful as biosorbent beads and thus modifications must be done to increase their biosorption ability.

Funding This work was supported by funding from a Deans Bequest grant (RJR) and a Doctoral scholarship (RJN) from the University of Otago. The authors would like to thank the Centre for Trace Element Analysis, Chemistry Department and Liz Girvan from the Otago Centre for Electron Microscopy, University of Otago for their assistance.

\section{Declarations}

Conflict of interest The authors have no competing interests.

Open Access This article is licensed under a Creative Commons Attribution 4.0 International License, which permits use, sharing, adaptation, distribution and reproduction in any medium or format, as long as you give appropriate credit to the original author(s) and the source, provide a link to the Creative Commons licence, and indicate if changes were made. The images or other third party material in this article are included in the article's Creative Commons licence, unless indicated otherwise in a credit line to the material. If material is not included in the article's Creative Commons licence and your intended use is not permitted by statutory regulation or exceeds the permitted use, you will need to obtain permission directly from the copyright holder. To view a copy of this licence, visit http://creativecommons.org/licenses/by/4.0/.

\section{References}

Abdolali A et al (2016) A breakthrough biosorbent in removing heavy metals: equilibrium, kinetic, thermodynamic and mechanism analyses in a lab-scale study. Sci Total Environ 542:603-611. https:// doi.org/10.1016/j.scitotenv.2015.10.095

Aichour A, Zaghouane-Boudiaf H, Iborra CV, Polo MS (2018) Bioadsorbent beads prepared from activated biomass/alginate for enhanced removal of cationic dye from water medium: kinetics, equilibrium and thermodynamic studies. J Mol Liq 256:533-540. https://doi.org/10.1016/j.molliq.2018.02.073

Akkaya G, Güzel F (2013) Optimization of copper and lead removal by a novel biosorbent: cucumber (Cucumis Sativus) peelskinetic, equilibrium, and desorption studies. J Dispers Sci Technol 34:1295-1307. https://doi.org/10.1080/01932691.2012.743863

Ali A, Saeed K, Mabood F (2016a) Removal of chromium (VI) from aqueous medium using chemically modified banana peels as efficient low-cost adsorbent. Alex Eng J 55:2933-2942. https:// doi.org/10.1016/j.aej.2016.05.011

Ali RM, Hamad HA, Hussein MM, Malash GF (2016b) Potential of using green adsorbent of heavy metal removal from aqueous solutions: adsorption kinetics, isotherm, thermodynamic, mechanism and economic analysis. Ecol Eng 91:317-332. https://doi.org/10. 1016/j.ecoleng.2016.03.015

Aliabadi M, Irani M, Ismaeili J, Piri H, Parnian MJ (2013) Electrospun nanofiber membrane of PEO/Chitosan for the adsorption of nickel, cadmium, lead and copper ions from aqueous solution. Chem Eng J 220:237-243. https://doi.org/10.1016/j.cej.2013.01.021

López ASJ, Li Q, Thompson IP (2010) Biorefinery of waste orange peel. Crit Rev in Biotechnol 30(1):63-69. https://doi.org/10.3109/ 07388550903425201

Augustin J, Toma RB, True RH, Shaw RL, Teitzel C, Johnson SR, Orr P (1979) Composition of raw and cooked potato peel and flesh: proximate and vitamin composition. J Food Sci 44(3):805-806

Banerjee S, Banerjee A, Sarkar P (2018) Statistical optimization of arsenic biosorption by microbial enzyme via Ca-alginate beads. J Environ Sci Health, Part A 53:436-442. https://doi.org/10.1080/ 10934529.2017.1409009

Beidokhti MZ, Naeeni STO, Abdi Ghahroudi MS (2019) Biosorption of nickel (II) from aqueous solutions onto pistachio hull waste as a low-cost biosorbent. Civil Eng J 5:447-457. https://doi.org/10. 28991/cej-2019-03091259

Boparai HK, Joseph M, O'Carroll DM (2013) Cadmium (Cd 2+) removal by nano zerovalent iron: surface analysis, effects of solution chemistry and surface complexation modeling. Environ Sci Pollut Res 20:6210-6221. https://doi.org/10.1007/ s11356-013-1651-8

Camire ME, Violette D, Dougherty MP, McLaughlin MA (1997) Potato peel dietary fiber composition: effects of peeling and extrusion cooking processes. J Agric Food Chem 45(4):1404-1408

Chand P, Pakade YB (2013) Removal of Pb from water by adsorption on apple pomace: equilibrium, kinetics, and thermodynamics studies. J Chem 2013:1-9. https://doi.org/10.1155/2013/164575

Ciesielczyk F, Bartczak P, Wieszczycka K, Siwińska-Stefańska K, Nowacka M, Jesionowski T (2013) Adsorption of Ni (II) from model solutions using co-precipitated inorganic oxides. Adsorption 19:423-434. https://doi.org/10.1007/s10450-012-9464-5

Cozmuta LM, Cozmuta AM, Peter A, Nicula C, Nsimba EB, Tutu $\mathrm{H}$ (2012) The influence of $\mathrm{pH}$ on the adsorption of lead by Naclinoptilolite: kinetic and equilibrium studies. Water SA 38:269278. https://doi.org/10.4314/wsa.v38i2.13

Crini G (2005) Recent developments in polysaccharide-based materials used as adsorbents in wastewater treatment. Prog Polym Sci 30:38-70. https://doi.org/10.1016/j.progpolymsci.2004.11.002

Deng S, Zhang G, Wang X, Zheng T, Wang P (2015) Preparation and performance of polyacrylonitrile fiber functionalized with iminodiacetic acid under microwave irradiation for adsorption of $\mathrm{Cu}$ (II) and $\mathrm{Hg}$ (II). Chem Eng J 276:349-357. https://doi.org/10.1016/j. cej.2015.04.043

El-Azazy M, El-Shafie AS, Issa AA, Al-Sulaiti M, Al-Yafie J, Shomar B, Al-Saad K (2019) Potato peels as an adsorbent for heavy metals from aqueous solutions: eco-structuring of a green adsorbent operating plackett-burman design. J Chem. https://doi.org/10. $1155 / 2019 / 4926240$

Emaga TH, Andrianaivo RH, Wathelet B, Tchango JT, Paquot M (2007) Effects of the stage of maturation and varieties on the chemical composition of banana and plantain peels. Food Chem 103(2):590-600. https://doi.org/10.1016/j.foodchem.2006.09.006

Feng N-c, Guo X-y (2012) Characterization of adsorptive capacity and mechanisms on adsorption of copper, lead and zinc by modified orange peel transactions of nonferrous metals. Soc China 22:1224-1231. https://doi.org/10.1016/S1003-6326(11)61309-5

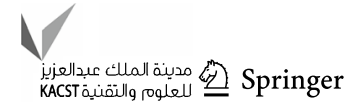


Geetha P, Latha MS, Pillai SS, Koshy M (2015) Nanoalginate based biosorbent for the removal of lead ions from aqueous solutions: equilibrium and kinetic studies. Ecotoxicol Environ Saf 122:1723. https://doi.org/10.1016/j.ecoenv.2015.06.032

Gerola GP, Boas NV, Caetano J, Tarley CRT, Gonçalves AC, Dragunski DC (2013) Utilization of passion fruit skin by-product as lead (II) ion biosorbent. Water Air Soil Pollut 224:1446. https://doi. org/10.1007/s11270-013-1446-Z

Gupta SS, Bhattacharyya KG (2011) Kinetics of adsorption of metal ions on inorganic materials: a review. Adv Coll Interface Sci 162:39-58. https://doi.org/10.1016/j.cis.2010.12.004

Iqbal M, Saeed A, Zafar SI (2009a) FTIR spectrophotometry, kinetics and adsorption isotherms modeling, ion exchange, and EDX analysis for understanding the mechanism of $\mathrm{Cd} 2+$ and $\mathrm{Pb} 2+$ removal by mango peel waste. J Hazard Mater 164:161-171. https://doi.org/10.1016/j.jhazmat.2008.07.141

Iqbal M, Schiewer S, Cameron R (2009b) Mechanistic elucidation and evaluation of biosorption of metal ions by grapefruit peel using FTIR spectroscopy, kinetics and isotherms modeling, cations displacement and EDX analysis. J Chem Technol Biotechnol 84:1516-1526. https://doi.org/10.1002/jctb.2212

Ivánová DANA, Horváthová HEDVIGA, Kaduková JANA, Kavulicova J (2010) Stability of immobilized biosorbents and its influence on biosorption of copper. Nova Biotechnol 10(1):45-51

Jain N (2015) Removal of heavy metal by using different fruit peels, vegetable peels and organic waste- a review. Int J 3:916-920

Jakóbik-Kolon A, Bok-Badura J, Karoń K, Mitko K, Milewski A (2017) Hybrid pectin-based biosorbents for zinc ions removal. Carbohyd Polym 169:213-219. https://doi.org/10.1016/j.carbpol.2017.03. 095

Jung W, Park YK, An J-s, Park JY, Oh HJ (2017) Sorption of arsenic and heavy metals using various solid phase materials. Int J Environ Sci Dev 8:71-74. https://doi.org/10.18178/ijesd.2017.8.2.923

Kajjumba GW, Emik S, Öngen A, Ozcan K, Aydin S (2018) Modelling of adsorption kinetic processes: errors, theory and application. In: Edebali S (ed) Advanced sorption process applications. IntechOpen, London, UK, pp 187-206

Kakalanga SJ, Jabulani XB, Olutoyin OB, Utieyin OO (2012) Screening of agricultural waste for $\mathrm{Ni}$ (II) adsorption: kinetics, equilibrium and thermodynamic studies. Int J Phy Sci 7:2525-2538. https://doi.org/10.5897/IJPS12.097

King AH (1983) Brown seaweed extracts (alginates). Food Hydrocolloids 2:115-188

Krishnani KK, Ayyappan S (2006) Heavy metals remediation of water using plants and lignocellulosic agrowastes. Rev Environ Contam Toxicol 188:59-84

Kumar R, Kim S-J, Kim K-H, Lee S-h, Park H-S, Jeon B-H (2018) Removal of hazardous hexavalent chromium from aqueous phase using zirconium oxide-immobilized alginate beads. Appl Geochem 88:113-121. https://doi.org/10.1016/j.apgeochem.2017.04. 002

Kurniawan TA, Chan GY, Lo W-h, Babel S (2006) Comparisons of low-cost adsorbents for treating wastewaters laden with heavy metals. Sci Total Environ 366:409-426. https://doi.org/10.1016/j. scitotenv.2005.10.001

Lesmana SO, Febriana N, Soetaredjo FE, Sunarso J, Ismadji S (2009) Studies on potential applications of biomass for the separation of heavy metals from water and wastewater. Biochem Eng J 44:1941. https://doi.org/10.1016/j.bej.2008.12.009

M'hiri N, Ioannou I, Ghoul M, Boudhrioua NM (2015) Proximate chemical composition of orange peel and variation of phenols and antioxidant activity during convective air drying. J New Sci JS-INAT 9:881-890

Malik D, Jain C, Yadav AK (2016) Removal of heavy metals from emerging cellulosic low-cost adsorbents: a review. Appl Water Sci 7:2113-2136. https://doi.org/10.1007/s13201-016-0401-8
Mashkoor F, Nasar A (2019) Preparation, characterization and adsorption studies of the chemically modified Luffa aegyptica peel as a potential adsorbent for the removal of malachite green from aqueous solution. J Mol Liq 274:315-327. https://doi.org/10.1016/j. molliq.2018.10.119

Mohamed HS, Soliman N, Abdelrheem DA, Ramadan AA, Elghandour $\mathrm{AH}$, Ahmed SA (2019) Adsorption of $\mathrm{Cd} 2+$ and $\mathrm{Cr} 3+$ ions from aqueous solutions by using residue of Padina gymnospora waste as promising low-cost adsorbent. Heliyon 5:e01287. https://doi. org/10.1016/j.heliyon.2019.e01287

Mohammadabadi SI, Javanbakht V (2020) Development of hybrid gel beads of lignocellulosic compounds derived from agricultural waste: efficient lead adsorbents for a comparative biosorption. J Mol Liq 315:113715. https://doi.org/10.1016/j.molliq.2020. 113715

Mohan D, Chander S (2001) Single component and multi-component adsorption of metal ions by activated carbons. Coll Surf, A 177:183-196

Mohapatra D, Mishra S, Sutar N (2010) Banana and its by-product utilisation: an overview. J Sci Ind Res 69:323-329

Mosa ZM, Khalil AF (2015) The effect of banana peels supplemented diet on acute liver failure rats. Ann Agric Sci 60(2):373-379. https://doi.org/10.1016/j.aoas.2015.11.003

Nasrullah A, Bhat A, Naeem A, Isa MH, Danish M (2018) High surface area mesoporous activated carbon-alginate beads for efficient removal of methylene blue. Int J Biol Macromol 107:1792-1799. https://doi.org/10.1016/j.ijbiomac.2017.10.045

Park CM, Han J, Chu KH, Al-Hamadani YA, Her N, Heo J, Yoon Y (2017) Influence of solution $\mathrm{pH}$, ionic strength, and humic acid on cadmium adsorption onto activated biochar: experiment and modeling. J Ind Eng Chem 48:186-193. https://doi.org/10.1016/j. jiec.2016.12.038

Paul E, Nwoken N, Anumonye F (2018) Biosorption of heavy metals $(\mathrm{Cd} 2+, \mathrm{Cr} 3+, \mathrm{Cu} 2+, \mathrm{Ni} 2+, \mathrm{Pb} 2+$ and $\mathrm{Zn} 2+)$ from aqueous solution onto activated carbon prepared from chicken feather. ATBU J Sci, Technol Educ 6:194-205

Pavithra S, Thandapani G, Sugashini S, Sudha PN, Alkhamis HH, Alrefaei AF, Almutairi MH (2021) Batch adsorption studies on surface tailored chitosan/orange peel hydrogel composite for the removal of $\mathrm{Cr}(\mathrm{VI})$ and $\mathrm{Cu}(\mathrm{II})$ ions from synthetic wastewater. Chemosphere 271:129415. https://doi.org/10.1016/j.chemosphere. 2020.129415

Plazinski W (2010) Applicability of the film-diffusion model for description of the adsorption kinetics at the solid/solution interfaces. Appl Surf Sci 256:5157-5163. https://doi.org/10.1016/j. apsusc.2009.12.083

Plazinski W, Dziuba J, Rudzinski W (2013) Modeling of sorption kinetics: the pseudo-second order equation and the sorbate intraparticle diffusivity. Adsorption 19:1055-1064. https://doi.org/10. 1007/s10450-013-9529-0

Pouya MR, Behnam S (2017) Adsorption behavior of copper ions on alga Jania adhaerens through SEM and FTIR analyses. Sep Sci Technol 52:2062-2068. https://doi.org/10.1080/01496395.2017. 1324492

Raza MH, Sadiq A, Farooq U, Athar M, Hussain T, Mujahid A, Salman M (2015) Phragmites karka as a biosorbent for the removal of mercury metal ions from aqueous solution: effect of modification. J Chem. https://doi.org/10.1155/2015/293054

Rehman S et al (2017) Simultaneous physisorption and chemisorption of reactive Orange 16 onto hemp stalks activated carbon: proof from isotherm modeling. Biointerface Res Appl Chem 7:2021-2029

Romero-González ME, Williams CJ, Gardiner PH (2001) Study of the mechanisms of cadmium biosorption by dealginated seaweed waste. Environ Sci Technol 35:3025-3030. https://doi.org/10. 1021/es991133r 
Sahmoune MN (2018) Thermodynamic properties of heavy metals ions adsorption by green adsorbents. In: Crini G, Lichtfouse E (eds) Green adsorbents for pollutant removal. Environmental chemistry for a sustainable world, vol 18. Springer, Cham, pp 193-213

Schiewer S, Iqbal M (2010) The role of pectin in Cd binding by orange peel biosorbents: a comparison of peels, depectinated peels and pectic acid. J Hazard Mater 177:899-907. https://doi.org/10. 1016/j.jhazmat.2010.01.001

Schiewer S, Patil SB (2008) Pectin-rich fruit wastes as biosorbents for heavy metal removal: equilibrium and kinetics. Biores Technol 99:1896-1903. https://doi.org/10.1016/j.biortech.2007.03.060

Schwantes D et al (2016) Chemical modifications of cassava peel as adsorbent material for metals ions from wastewater. J Chem. https://doi.org/10.1155/2016/3694174

Schwarzenbach RP, Egli T, Hofstetter TB, Von Gunten U, Wehrli B (2010) Global water pollution and human health. Annu Rev Environ Resour 35:109-136. https://doi.org/10.1146/annurev-envir on-100809-125342

Semerjian L (2018) Removal of heavy metals $(\mathrm{Cu}, \mathrm{Pb})$ from aqueous solutions using pine (Pinus halepensis) sawdust: equilibrium, kinetic, and thermodynamic studies. Environ Technol Innov 12:91-103. https://doi.org/10.1016/j.eti.2018.08.005

Sepelev I, Galoburda R (2015) Industrial potato peel waste application in food production: a review. Res Rural Dev 1:130-136

Shrestha B, Kour J, Homagai PL, Pokhrel MR, Ghimire KN (2013) Surface modification of the biowaste for purification of wastewater contaminated with toxic heavy metals: lead and cadmium. Adv Chem Eng Sci 3:178-184. https://doi.org/10.4236/aces.2013. 33022P

Singh RJ, Martin CE, Barr D, Rosengren RJ (2019a) Immobilised apple peel bead biosorbent for the simultaneous removal of heavy metals from cocktail solution. Cogent Environ Sci 5:1673116. https://doi.org/10.1080/23311843.2019.1673116

Singh RJ, Martin CE, Barr D, Rosengren RJ (2019b) Cucumber peel bead biosorbent for multi-ion decontamination of drinking water collected from a mine region in New Zealand. Environ Technol. https://doi.org/10.1080/09593330.2019.1703824

Stavrinou A, Aggelopoulos C, Tsakiroglou C (2018) Exploring the adsorption mechanisms of cationic and anionic dyes onto agricultural waste peels of banana, cucumber and potato: adsorption kinetics and equilibrium isotherms as a tool. J Environ Chem Eng 6:6958-6970. https://doi.org/10.1016/j.jece.2018.10.063

Tan K, Hameed B (2017) Insight into the adsorption kinetics models for the removal of contaminants from aqueous solutions. J Taiwan Inst Chem Eng 74:25-48. https://doi.org/10.1016/j.jtice.2017.01. 024

Thakur RS, Chaudhary R, Singh C (2015) Influence of pH on photocatalytic reduction, adsorption, and deposition of metal ions: speciation modeling. Desalin Water Treat 56:1335-1363. https:// doi.org/10.1080/19443994.2014.944222

Toma RB, Orr PH, D’appolonia B, Dlntzis FR, Tabekhia MM (1979) Physical and chemical properties of potato peel as a source of dietary fiber in bread. J Food Sci 44(5):1403-1407

UNESCO World Water Assessment Programme (2019) The united nationsworld water development report 2019. UNESCO World Water Assessment Programme, Colombella, Perugia, Italy

Van Thuan T, Quynh BTP, Nguyen TD, Bach LG (2017) Response surface methodology approach for optimization of $\mathrm{Cu} 2+, \mathrm{Ni} 2+$ and $\mathrm{Pb} 2+$ adsorption using $\mathrm{KOH}$-activated carbon from banana peel. Surf Interfaces 6:209-217. https://doi.org/10.1016/j.surfin. 2016.10.00

Vu HC, Dwivedi AD, Le TT, Seo S-H, Kim E-J, Chang Y-S (2017) Magnetite graphene oxide encapsulated in alginate beads for enhanced adsorption of $\mathrm{Cr}(\mathrm{VI})$ and $\mathrm{As}(\mathrm{V})$ from aqueous solutions: role of crosslinking metal cations in $\mathrm{pH}$ control. Chem Eng J 307:220-229. https://doi.org/10.1016/j.cej.2016.08.058

Wang R, Liang R, Dai T-t, Chen J, Shuai X, Liu C (2019) Pectin-based adsorbents for heavy metal ions: a review. Trends Food Sci Technol. https://doi.org/10.1016/j.tifs.2019.07.033

Wang R-Z et al (2018) Investigating the adsorption behavior and the relative distribution of $\mathrm{Cd} 2+$ sorption mechanisms on biochars by different feedstock. Biores Technol 261:265-271. https://doi.org/ 10.1016/j.biortech.2018.04.032

Wang S, Vincent T, Faur C, Guibal E (2016a) Alginate and algal-based beads for the sorption of metal cations: $\mathrm{Cu}$ (II) and $\mathrm{Pb}$ (II). Int $\mathrm{J}$ Mol Sci 17:1453. https://doi.org/10.3390/ijms17091453

Wang Z, Huang Y, Wang M, Wu G, Geng T, Zhao Y, Wu A (2016b) Macroporous calcium alginate aerogel as sorbent for $\mathrm{Pb} 2+$ removal from water media. J Environ Chem Eng 4:3185-3192. https://doi.org/10.1016/j.jece.2016.06.032

Witczak T, Witczak M, Socha R, StĘPień A, Grzesik M (2017) Candied orange peel produced in solutions with various sugar compositions: sugar composition and sorption properties of the product. J Food Process Eng 40(2):e12367. https://doi.org/10.1111/jfpe. 12367

Zhang D, Wang C, Bao Q, Zheng J, Deng D, Duan Y, Shen L (2018) The physicochemical characterization, equilibrium, and kinetics of heavy metal ions adsorption from aqueous solution by arrowhead plant (Sagittaria trifolia L.) stalk. J Food Biochem 42:12448. https://doi.org/10.1111/jfbc. 12448

Publisher's Note Springer Nature remains neutral with regard to jurisdictional claims in published maps and institutional affiliations. 